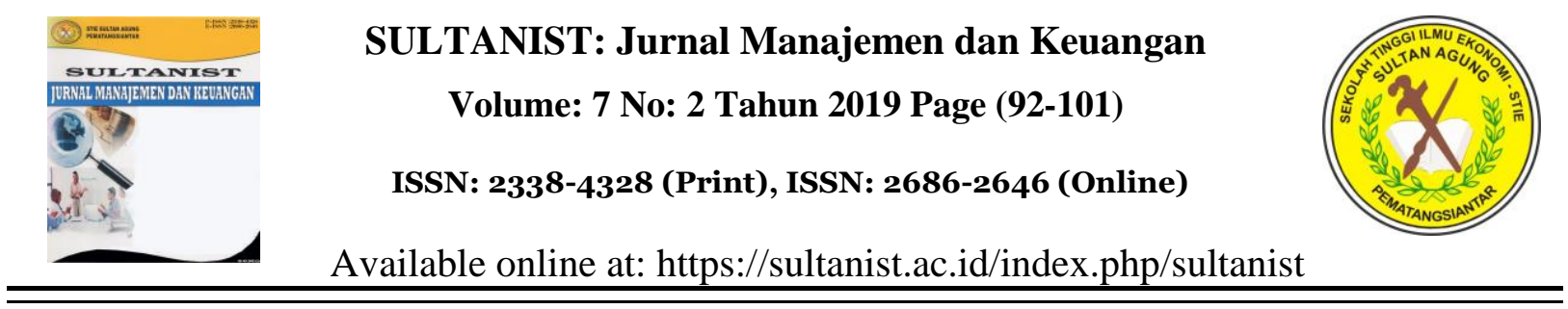

\title{
DAMPAK STRUKTUR ASET DAN UKURAN PERUSAHAAN TERHADAP STRUKTUR MODAL
}

\author{
Verda Desi Yolanda Panggabean ${ }^{1}$, Ady Inrawan², Hery Pandapotan Silitonga ${ }^{3}$, Lenny \\ Dermawan Sembiring ${ }^{4}$ \\ Program Studi Manajemen, Sekolah Tinggi Ilmu Ekonomi Sultan Agung, \\ verdapanggabean96@gmail.com \\ Program Studi Manajemen, Sekolah Tinggi Ilmu Ekonomi Sultan Agung, \\ adyinrdr@gmail.com, herysilitonga@gmail.com, lennydsembiring@gmail.com
}

\begin{abstract}
Abstrak
Tujuan penelitan ini untuk mengetahui pengaruh struktur aset dan ukuran perusahaan terhadap struktur modal. Metode yang digunakan analisis deskriptif kuantitatif. Analisis data digunakan uji asumsi klasik, regresi linier berganda, koefisien korelasi, determinasi, uji F dan uji t. objek pada Perusahaan Sub Sektor perkebunan yang terdaftar di Bursa Efek Indonesia untuk laporan keuangan periode 2011-2017. Hasil penelitian dapat disimpulkan sebagai berikut: 1. Hasil pengujian analisis regresi linear berganda diketahui bahwa struktur aset berpengaruh positif, sedangkan ukuran perusahaan berpengaruh negatif terhadap struktur modal. 2. Hasil koefisien korelasi menunjukkan bahwa hubungan struktur aset dan ukuran perusahaan terhadap struktur modal berada pada tingkat yang sedang, sedangkan koefesien determinasi sebesar 27,40\% tinggi rendahnya struktur modal dapat dijelaskan oleh struktur aset dan ukuran perusahaan 3. Uji Hipotesis, untuk hasil uji F adalah struktur aset dan ukuran perusahaan berpengaruh signifikan terhadap struktur modal, dan uji t bahwa struktur aset berpengaruh signifikan terhadap struktur modal dan ukuran perusahaan berpengaruh tidak signifikan terhadap struktur modal.
\end{abstract}

Kata Kunci : Struktur Aset, Ukuran Perusahaan, Struktur Modal.

\section{THE IMPACT OF COMPANY ASSETS AND SIZES ON CAPITAL STRUCTURES}

\begin{abstract}
The purpose of this research are to determine the effect of the asset structure and size of the company on the capital structure. The research was conducted using quantitative descriptive analysis. The analysis technique used is classic assumption test, multiple linear regression, correlation coefficient, determination, $t$ test, and test F. Objects on plantation sub-sector companies listed on the Indonesia Stock Exchange of financial statements for the periode 2011-2017.. The result of this research can be summarized as follows: 1. The result of testing multiple linear regression analysis are known that the asset structure has positive effect on capital structure, while the size has negative effect on capital structure. 2. Correlation coefficient results show that the relationship of asset structure and firm size to capital structure is at a moderate level, while the coefficient of determination of $27.40 \%$ high or low capital structure can be explained by the asset structure and company size. 3. The result of the F test can be concluded that simultaneously the asset structure and size has a significant effect on capital structure. The t test result can be concluded that partially the asset structure has a significant effect on capital structure and the company size has no significant effect on capital structure.
\end{abstract}

Keywords: Asset Structure, Size, Capital Structure 



\section{PENDAHULUAN}

Perkembangan perusahan dalam upaya mengantisipasi persaingan yang semakin ketat seperti saat ini akan selalu dilakukan dengan baik oleh perusahaan besar maupun perusahaan kecil. Upaya tersebut merupakan permasalahan tersendiri bagi perusahaan, karena menyangkut pemenuhan dana yang diperlukan. Perubahan kondisi lingkungan ekonomi banyak berpengaruh pada lingkungan usaha, dan tidak semua sektor mampu bertahan dalam perubahan kondisi lingkungan ekonomi tersebut. Banyak perusahaan melakukan berbagai cara untuk mengembangkan usahanya, dan tentulah tidak sedikit dana yang dibutuhkan perusahaan untuk mengembangkan serta menjalankan kegiatan-kegiatan usaha perusahaan. Salah satu faktor untuk memenangkan persaingan tersebut adalah struktur modal.

Struktur modal adalah proporsi penggunaan antara utang dan ekuitas. Manajemen sebagai pengelola perusahaan tentu harus dapat menyeimbangkan penggunaan utang dan ekuitas untuk mencapai struktur modal yang optimal. Salah satu faktor yang mempengaruhi struktur modal adalah struktur aset. Struktur aset adalah rasio perbandingan antara aset lancar dan aset tetap terhadap total aset yang dilakukan sebagai penentuan alokasi besarnya alokasi dana untuk masing-masing komponen aset. Struktur aset dapat diukur menggunakan Tangibility of Asset Ratio, adalah proporsi aset tetap perusahaan terhadap total aset perusahaan secara keseluruhan. Faktor lain yang mempengaruhi struktur aset adalah ukuran perusahaan. Ukuran perusahaan adalah nilai yang menunjukkan besar kecilnya perusahaan yang ditunjukkan oleh total aset, jumlah penjualan, rata-rata total penjualan dan rata-rata total aset. Ukuran perusahaan dapat diukur menggunakan size. Size adalah ukuran besarnya aset yang dimiliki perusahaan.

Penelitian ini dilakukan pada Perusahaan Sub Sektor perkebunan yang terdaftar di Bursa Efek Indonesia. Berikut ini disajikan gambaran Tangibly of Asset Ratio, size dan long term debt to equity pada Perusahaan Perusahaan Sub Sektor perkebunan yang terdaftar di Bursa Efek Indonesia periode 2011-2017:

Tabel 1. Gambaran Struktur Aset, Ukuran Perusahaan dan Struktur Modal pada Perusahaan Sub Sektor Perkebunan yang Terdaftar di Bursa Efek Indonesia Tahun 2011 sampai dengan 2017

\begin{tabular}{|c|c|c|c|}
\hline \multirow{2}{*}{ Tahun } & Struktur Aset & $\begin{array}{c}\text { Ukuran } \\
\text { Perusahaan } \\
\end{array}$ & $\begin{array}{c}\begin{array}{c}\text { Struktur } \\
\text { Modal }\end{array} \\
\end{array}$ \\
\hline & $\begin{array}{c}\begin{array}{c}\text { Tangibility of Aset Ratio } \\
\text { (kali) }\end{array} \\
\end{array}$ & Size (kali) & $\begin{array}{c}\text { LtDER } \\
\text { (kali) }\end{array}$ \\
\hline 2011 & 0,36 & 29,61 & 0,43 \\
\hline 2012 & 0,41 & 29,75 & 0,65 \\
\hline 2013 & 0,43 & 29,88 & 0,59 \\
\hline 2014 & 0,45 & 30,02 & 0,58 \\
\hline 2015 & 0,47 & 30,15 & 0,77 \\
\hline 2016 & 0,41 & 30,23 & 0,65 \\
\hline 2017 & 0,44 & 30,22 & 0,63 \\
\hline $\begin{array}{l}\text { Rata- } \\
\text { rata }\end{array}$ & 0,45 & 29,95 & 0,61 \\
\hline
\end{tabular}

Sumber: Laporan Keuangan Perusahaan Sub Sektor Perkebunan (Data diolah 2019)

Dari Tabel 1 di atas dapat diketahui bahwa variabel struktur aset yang menggunakan parameter Tangibility of Asset Ratio tahun 2011 sampai dengan 2017 mengalami fluktuasi dan cenderung meningkat. Menurut Brigham dan Joel (2006), yang mengatakan bahwa "perusahaan yang aktivanya cocok sebagai jaminan atas pinjaman cenderung lebih banyak menggunakan utang. Aktiva untuk tujuan umum yang dapat digunakan oleh banyak bisnis dapat menjadikan jaminan yang baik, dan sebaliknya pada aktiva untuk tujuan khusus. Sedangkan pada variabel ukuran perusahaan dengan menggunakan parameter size mengalami fluktuasi dan cenderung meningkat. Secara langsung keputusan struktur modal akan mempengaruhi kondisi dan nilai perusahaan serta menentukan kemampuan perusahaan untuk tetap bertahan dan berkembang. . Menurut Sawir (2004), yang mengatakan "ukuran perusahaan menggambarkan ukuran besar kecilnya suatu perusahaan yang ditunjukkan oleh total aset, jumlah penjualan, rata-rata total penjualan dan ratarata total aset. Semakin besar ukuran perusahaan menunjukkan semakin tinggi kemampuan perusahaan mendapatkan 
modal di pasar modal dan semakin besar perusahaan, maka akan semakin tinggi pula dana yang dibutuhkan untuk membiayai kebutuhan perusahaan.

Rumusan masalah dalam penelitian ini adalah bagaimana gambaran struktur aset, ukuran perusahaan dan struktur modal, dan bagaimana pengaruh struktur aset dan ukuran perusahaan terhadap struktur modal pada perusahaan Sub Sektor perkebunan yang terdaftar di Bursa Efek Indonesia. berdasarkan rumusan masalah di atas maka tujuan penelitian ini adalah untuk mengetahui gambaran struktur aset, ukuran perusahaan dan struktur modal, dan mengetahui pengaruh struktur aset dan ukuran perusahaan terhadap struktur modal pada perusahaan Sub Sektor perkebunan baik secara simultan maupun parsial yang terdaftar di Bursa Efek Indonesia. Kegunaan penelitian ini adalah sebagai bahan pertimbangan bagi perusahaan dalam pengambilan keputusan untuk dapat mempredksi struktur aset dan ukuran perusahaan yang berpengaruh pada perkembangan struktur modal perusahaan.

\section{LANDASAN TEORI}

\section{Akuntansi}

Dalam pengambilan keputusan diperlukan adanya sebuah sistem informasi yang mengukur aktivitas bisnis, mengolah data menjadi laporan serta mengkomunikasikan hasilnya kepada para pengambil keputusan. Menurut Rudianto (2012), menyatakan bahwa akuntansi adalah sistem informasi yang menghasilkan laporan kepada pihak-pihak yang berkepentingan mengenai aktivitas ekonomi dan kondisi perusahaan. Berdasarkan pengertian akuntansi yang telah dikemukakan di atas, maka dapat disimpulkan bahwa akuntansi adalah proses pengidentifikasian, pengukuran, pencatatan seluruh aktivitas bisnis atau kejadian-kejadian ekonomi dalam suatu organisasi untuk membuat pertimbangan dan mengambil keputusan yang tepat bagi pemakainya.

\section{Analisa Laporan Keuangan}

Analisa laporan keuangan pada dasarnya merupakan penghitungan rasiorasio untuk menilai keadaan keuangan perusahaan di masa lalu, pada saat ini dan meramalkan kemungkinan yang akan terjadi dimasa depan yang berguna bagi pengambilan keputusan. Menurut Horne dan John (2012), "analisis laporan keuangan adalah seni untuk mengubah data dari laporan keuangan ke informasi yang berguna bagi pengambilan keputusan. Analisis laporan keuangan melibatkan berbagai laporan keuangan. Laporan ini melaksanakan beberapa fungsi. Pertama, laporan posisi keuangan atau neraca meringkas aset, liabilities, dan ekuitas pemilik suatu perusahaan pada suatu periode, biasanya pada akhir tahun atau kuartal. Sementara laporan laba rugi meringkas pendapatan dan biaya perusahaan selama suatu periode waktu tertentu. Maka dapat disimpulkan bahwa analisa laporan keuangan adalah seni untuk mengubah data dari laporan keuangan ke informasi yang berguna untuk pengambilan keputusan serta meneliti hubungan yang ada diantara unsurunsur pada laporan keuangan, dan membandingkan unsur-unsur yang selama satu tahun lalu atau angka pembanding lain serta menjelaskan penyebab perubahannya.

\section{Struktur Aset}

Sumber daya ekonomi atau kekayaan yang dimiliki suatu perusahaan baik dalam bentuk benda maupun hak kuasa yang diperoleh di masa lalu serta diharapkan dapat memberikan manfaat di masa depan disebut dengan aset. Menurut Sudana (2011), "perusahaan dengan komposisi aktiva lancar yang lebih besar dari pada komposisi aktiva tetap terhadap total aktiva, dapat menggunakan utang yang lebih besar untuk membelanjai investasinya dibandingkan dengan perusahaan yang komposisi aktiva tetapnya lebih besar dibandingkan dengan aktiva lancar. Tangibility of Asset Ratio adalah proporsi aset tetap perusahaan terhadap total aset perusahaan secara keseluruhan. Alasan menggunakannya karena Tangibility of Asset Ratio dapat melihat seberapa besarnya 
aset tetap perusahaan untuk menjamin pinjaman atau hutang pada perusahaan.

\section{Ukuran Perusahaan}

Salah satu faktor yang mempengaruhi nilai perusahaan adalah ukuran perusahaan. Menurut Hery (2017), mengatakan ukuran perusahaan adalah suatu skala di mana dapat diklasifikasikan besar kecilnya perusahaan menurut berbagai cara antara lain dengan total aset, nilai pasar saham dan lain-lain. Size adalah ukuran perusahaan dilakukan dengan rumus logaritma dari total aktiva. Size digunakan untuk mengurangi fluktuasi data yang berlebih dan meminimalisir standard eror.

\section{Struktur Modal}

Struktur modal didefinisikan sebagai perimbangan atau perbandingan antara jumlah hutang jangka panjang dengan modal sendiri. Menurut Sudana (2011), mengatakan bahwa struktur modal (capital structure) berkaitan dengan pembelanjaan jangka panjang suatu perusahaan yang diukur dengan perbandingan utang jangka panjang dengan modal sendiri. Rasio LtDER adalah rasio untuk mengukur besar kecilnya penggunaan utang jangka panjang dibandingkan modal sendiri perusahaan. Rasio ini menggambarkan hubungan antara hutang jangka panjang dengan ekuitas (modal). Rasio ini menunjukkan bagian dari setiap rupiah modal sendiri yang dijadikan jaminan untuk hutang jangka panjang.

\section{Pengaruh Struktur Aset Terhadap Struktur Modal}

Struktur aset menggambarkan sebagian jumlah aset yang dapat dijadikan jaminan. Secara umum, perusahaan yang memiliki aktiva yang dapat digunakan sebagai agunan hutang cenderung menggunakan hutang relatif lebih besar. Menurut Brigham dan Joel (2006), menyatakan perusahaan yang aktivanya cocok sebagai jaminan atas pinjaman cenderung lebih banyak menggunakan utang. Aktiva untuk tujuan umum yang dapat digunakan oleh banyak bisnis dapat menjadi jaminan yang baik, dan sebaliknya pada aktiva untuk tujuan khusus. struktur aset dapat digunakan untuk menentukan seberapa besar utang jangka panjang yang dapat diambil dan hal ini akan berpengaruh terhadap penentuan besarnya struktur modal. Sejalan dengan penelitian yang dilakukan Batubara Topowijono, dan Zahro (2017), dan Ginting (2017), bahwa struktur aktiva berpengaruh signifikan terhadap struktur modal.

\section{Pengaruh Struktur Perusahaan Terhadap Struktur Modal \\ Ukuran perusahaan merupakan} gambaran kemampuan finansial perusahaan dalam suatu periode tertentu. Besar kecilnya perusahaan berpengaruh pada struktur modal dengan didasarkan pada kenyataan bahwa perusahaan besar dapat membiayai investasinya dengan mudah lewat pasar modal. Menurut Sawir (2004), menyatakan ukuran perusahaan menggambarkan ukuran besar kecilnya suatu perusahaan yang ditunjukkan oleh total aset, jumlah penjualan, rata-rata total penjualan dan ratarata total aset. Semakin besar ukuran perusahaan menunjukkan semakin tinggi kemampuan perusahaan mendapatkan modal di pasar modal dan semakin besar perusahaan, maka akan semakin tinggi pula dana yang dibutuhkan untuk membiayai kebutuhan perusahaan. Oleh sebab itu terdapat hubungan positif antara ukuran perusahaan dengan struktur modal. Hal ini sejalan dengan penelitian yang dilakukan Batubara Topowijono, dan Zahro (2017), Santoso (2016) Wahome, Memba and Willy (2015).

\section{METODE PENELITIAN}

\section{Jenis Penelitian}

Pendekatan penelitian yang digunakan dalam penelitian ini adalah pendekatan asosiatif. Desain penelitian yang digunakan penulis adalah penelitian kepustakaan (library research). Data yang diperoleh melalui penelitian ini adalah data sekunder berwujud teori, konsep lain-lain.

\section{Waktu dan Tempat Penelitian}

Waktu penelitian ini dilakukan selama kurang lebih empat bulan, pada bulan 
Febuari 2019-Mei 2019. Tempat penelitian dilakukan pada Perusahaan Sub Sektor Perkebunan yang terdaftar di Bursa Efek Indonesia.

\section{Subjek Penelitian}

Subjek penelitian ini adalah terbatas pada laporan keuangan yang sudah diaudit pada Perusahaan Sub Sektor Perkebunan yang terdaftar di Bursa Efek Indonesia. Teknik pengambilan sampel pada penelitian ini menggunakan nonprobability sampling dengan metode purposive sampling. Penarikan sampel berdasarkan kriteria di atas dapat dilihat pada tabel 2 berikut:

Tabel 2. Proses Seleksi Perusahaan

\section{Populasi}

\begin{tabular}{|l|l|l|}
\hline $\begin{array}{l}\text { Perusahaan Sub Sektor Perkebunan yang } \\
\text { terdaftar di Bursa Efek Indonesia Per 31 Des }\end{array}$ & 16 \\
2017 & & \\
\hline $\begin{array}{l}\text { Perusahaan Sub Sektor Perkebunan yang } \\
\text { terdaftar di Bursa Efek Indonesia yang tidak }\end{array}$ & \\
mempublikasikan Laporan Keuangan secara & (5) \\
lengkap yang telah diaudit selama periode & \\
$2011-2017$ & & \\
\hline $\begin{array}{l}\text { Perusahaan Sub Sektor Perkebunan yang } \\
\text { terdaftar di Bursa Efek Indonesia yang pernah }\end{array}$ & \\
mengalami Rugi 3 Tahun Berturut-turut selama \\
periode 2011-2017
\end{tabular}

Jenis data yang digunakan dalam penelitian ini adalah data kuantitatif. Data kuantitatif dalam penelitian ini adalah laporan keuangan perusahaan yang termasuk Sub Sektor Perkebunan yang Terdaftar di Bursa Efek Indonesia selama periode 20112017.

\section{Teknik Pengumpulan Data}

Teknik pengumpulan data dilakukan penulis dalam penelitian ini adalah metode dokumentasi dengan cara mengumpulkan data dan informasi melalui buku-buku karangan ilmiah, referensi dan menggunakan media elektronik untuk searching.

\section{Teknik Analisis Data}

Teknik analisis data yang digunakan oleh penulis dalam penelitian ini adalah sebagai berikut berupa Analisis Deskriptif kuantitatif, Uji Asumsi Klasik, Analisis Regresi Linear Berganda, Uji Hipotesis, Koefesien Korelasi dan determinasi.

\section{HASIL DAN PEMBAHASAN}

\section{Uji Asumsi Klasik}

Hasil pengujian hipotesis yang baik adalah pengujian yang tidak melanggar asumsiasumsi klasik yang mendasari model regresi linear berganda. Uji asumsi klasik yang terdapat dalam penelitian ini terdiri dari:

\section{Uji Normalitas}

Untuk uji normalitas dalam penelitian ini menggunakan kolmogorov-Smirnov test. Berikut tabel hasil uji normalitas dengan menggunakan kolmogorov-Smirnov test sebagai berikut:

Tabel 3. Hasil Uji Normalitas

One-Sample Kolmogorov-Smirnov Test

\begin{tabular}{|ll|r|}
\hline & & \multicolumn{2}{|c|}{ Unstandardized Residual } \\
\hline $\mathrm{N}$ & & 49 \\
Normal & Mean & $0 \mathrm{E}-7$ \\
Parameters & ,b & Std. \\
& Deviation &, 38877509 \\
Most & Absolute &, 117 \\
Extreme & Positive &, 117 \\
Differences & Negative &,- 066 \\
Kolmogorov-Smirnov Z &, 818 \\
Asymp. Sig. (2-tailed) &, $\mathbf{5 1 6}$ \\
\hline
\end{tabular}

a. Test distribution is Normal.

b. Calculated from data.

Sumber: Hasil pengolahan data (2019)

Dari tabel 3 dapat terlihat Sig. (2-tailed) variabel Unstandardized Residual adalah 0,516 yang berada diatas nilai signifikan 0,05 atau 0,516>0,05. Dengan demikian dapat dikatakan bahwa variabel berdistribusi normal.

\section{Uji Mulitkolineritas}

Uji multikolinearitas yang digunakan dalam penelitian ini adalah uji multikolinearitas dengan TOL (Tolerance) dan Varince Inflation Factor (VIF), dengan hasil pengujian dalam Tabel 4 berikut ini: 
Tabel 4. Hasil Uji Multikolinearitas Coefficients $^{\mathrm{a}}$

\begin{tabular}{|c|c|c|}
\hline \multirow[t]{2}{*}{ Model } & \multicolumn{2}{|c|}{ Collinearity Statistics } \\
\hline & Tolerance & VIF \\
\hline (Cons & & \\
\hline 1 TAR & ,791 & 1,264 \\
\hline SIZE & ,791 & 1,264 \\
\hline
\end{tabular}

a. Dependent Variable: LTDER

Sumber: Hasil pengolahan data (2019)

Dari tabel 4 dapat dilihat bahwa nilai VIF Tangibility of Asset Ratio sebesar 1,264 dan Size sebesar 1,264. Dengan demikian Variance Inflation Factor (VIF) lebih kecil dari 10, maka pada model regresi yang terbentuk tidak terjadi gejala multikolinearitas.

\section{Uji Heterokedasitas}

Dalam penelitian ini, penulis menggunakan metode grafik sebagai dasar pengambilan keputusan untuk menilai apakah scattterplot di sumbu horizontal yang menggambarkan nilai predicted dan sumbu vertikal yang menggambarkan residual studentized membentuk pola penyebaran tidak acak atau setiap data merapat dan saling tertimpa, maka dapat disimpulkan bahwa terjadi gejala heteroskedastisitas.

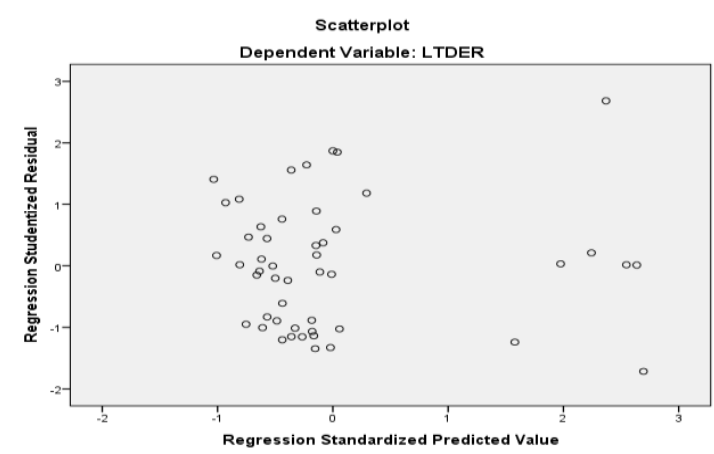

Sumber: Hasil pengolahan data (2019)

\section{Gambar 1. Hasil Uji Heteroskedastisitas}

Dari gambar 1 di atas terlihat bahwa titik-titik sudah menyebar secara acak di atas maupun di bawah angka 0 pada sumbu Y. Maka berdasarkan uji heteroskedastisitas menggunakan metode analisis grafik, pada model regresi yang terbentuk disimpulkan tidak terjadi gejala heteroskedastisitas.

\section{Uji Autokorelasi}

Pengujian autokorelasi dilakukan adalah dengan metode Durbin-Watson. Uji autokorelasi ini merupakan uji yang sangat populer untuk menguji ada atau tidaknya autokorelasi dari model empiris yang diestimasi.

Tabel 5. Hasil Uji Autokorelasi Model Summary ${ }^{\mathrm{b}}$

\begin{tabular}{|c|c|c|}
\hline Model & $\begin{array}{l}\text { Std. Error of the } \\
\text { Estimate }\end{array}$ & Durbin-Watson \\
\hline 1 & ,3971368 & 1,966 \\
\hline
\end{tabular}

Sumber: Hasil pengolahan data (2019)

Dari tabel 5 terlihat bahwa nilai DurbinWatson adalah 1,966. Berdasarkan tabel DW pada lampiran dengan signifikansi 0,05 dan jumlah data $(n)=49$ dan $(k)=2$. Berdasarkan tabel Durbin-Watson didapatkan nilai du sebesar 1,6257 dan 4-du $=4-1,6257=2,3743$, sedangkan nilai $\mathrm{dl}=$ 1,4564. Maka uji Durbin-Watson sebesar 1,966 berada pada du $\mathrm{d} 4$ - du atau dapat dijelaskan bahwa 1,6257 1,966 2,3743. Dengan demikian dapat disimpulkan bahwa model persamaan regresi tersebut dinyatakan tidak ada autokorelasi positif atau negatif atau dinyatakan tidak ditolak.

\section{Analisis Regresi Linear Berganda}

Analisis regresi ini sering digunakan untuk mengetahui ada tidaknya pengaruh variabel bebas, yakni struktur aset dan ukuran perusahaan terhadap variabel terikat yaitu struktur modal, maka perlu dilakukan analisis regresi linear berganda. Untuk melakukan regresi berganda menggunakan alat bantu software SPSS versi 23:

Tabel 6. Hasil Analisis Regresi Linear Berganda

\begin{tabular}{|c|c|c|c|}
\hline \multirow[t]{2}{*}{ Model } & \multicolumn{2}{|c|}{$\begin{array}{l}\text { Unstandardized } \\
\text { Coefficients }\end{array}$} & $\begin{array}{c}\text { Standardized } \\
\text { Coefficients }\end{array}$ \\
\hline & B & $\begin{array}{l}\text { Std. } \\
\text { Error }\end{array}$ & Beta \\
\hline (Constant) & ,922 & 2,619 & \\
\hline 1 TAR & 1,229 & ,347 &, 501 \\
\hline SIZE &,- 028 & ,085 &,- 046 \\
\hline
\end{tabular}

a. Dependent Variable: LTDER

Sumber: Hasil pengolahan data (2019) 
Berdasarkan hasil analisis regresi linear berganda di atas, maka model persamaan regresi adalah sebagai berikut:

$$
\hat{\mathbf{Y}}=3,360+1,229 \mathrm{X}_{1}-\mathbf{0 , 0 2 8 X _ { 2 }}
$$

Artinya struktur aset berpengaruh positif dan ukuran perusahaan berpengaruh negatif terhadap struktur modal pada Perusahaan Sub Sektor Perkebunan yang terdaftar di Bursa Efek Indonesia periode 2011-2017.

\section{Koefisien Korelasi dan Koefisien Determinasi}

Hasil pengolahan data menggunakan SPSS untuk menunjukkan koefisien korelasi dan koefisien determinasi sebagai berikut:

Tabel 7. Hasil Analisis Koefisien Korelasi dan Koefisien Determinasi Model Summary ${ }^{\mathrm{b}}$

\begin{tabular}{|l|c|r|r|r|}
\hline Model & $\mathrm{R}$ & $\begin{array}{c}\mathrm{R} \\
\text { Square }\end{array}$ & $\begin{array}{c}\text { Adjusted R } \\
\text { Square }\end{array}$ & $\begin{array}{r}\text { Std. Error of } \\
\text { the Estimate }\end{array}$ \\
\hline 1 & $\mathbf{, 5 2 3}^{\mathrm{a}}$ & $\mathbf{2 7 4}$ &, 242 &, 3971368 \\
\hline
\end{tabular}
a. Predictors: (Constant), SIZE, TAR
b. Dependent Variable: LTDER

Sumber: Hasil pengolahan data (2019)

Berdasarkan tabel 7 diperoleh hasil dari koefisien $r$ sebesar 0,523 yang artinya terdapat korelasi atau hubungan yang sedang antara struktur modal dengan struktur aset dan ukuran perusahaan. Sedangkan nilai koefisien determinasinya ( $R$ square) sebesar 0,274 yang berarti $27,40 \%$ tinggi rendahnya struktur modal dapat dijelaskan oleh struktur aset dan ukuran perusahaan, sedangkan sisanya dipengaruhi oleh faktor lain yang tidak dimasukkan dalam penelitian ini seperti risiko usaha, posisi pajak perusahaan, bussiness risk, tax position dan sebagainya yang memiliki nilai $72,60 \%$.

\section{Uji Hipotesis}

\section{Uji Simultan (Uji F)}

Uji simultan (uji F) digunakan untuk menguji apakah variabel bebeas yang digunakan dalam model sregresi mampu menjelaskan perubahan nilai variabel tergantung atau tidak.
Tabel 8. Hasil Uji F $\operatorname{ANOVA}^{\mathrm{a}}$

\begin{tabular}{|l|c|c|c|c|c|}
\hline Model & $\begin{array}{c}\text { Sum of } \\
\text { Squares }\end{array}$ & Df & $\begin{array}{c}\text { Mean } \\
\text { Square }\end{array}$ & F & Sig. \\
\hline \multirow{2}{*}{ Regression } & 2,737 & 2 & 1,369 & $\mathbf{8 , 6 7 7}$ & $\mathbf{, 0 0 1}^{\text {b }}$ \\
Residual & 7,255 & 46 &, 158 & & \\
$\quad$ Total & 9,992 & 48 & & & \\
\hline
\end{tabular}

a. Dependent Variable: LTDER

b. Predictors: (Constant), SIZE, TAR

Sumber: Hasil pengolahan data (2019)

Berdasarkan tabel 8, diperoleh nilai

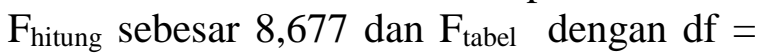
$(49-2-1)=46$, maka diperoleh $F_{\text {tabel }}$ sebesar $=3,20$. Hal ini menunjukkan bahwa $F_{\text {hitung }}>$ $F_{\text {tabel }}(8,677>3,20)$ atau signifikan $0,001<$ 0,05 , maka $\mathrm{H}_{0}$ ditolak, artinya struktur aset dan ukuran perusahaan berpengaruh positif dan signifikan terhadap struktur modal pada perusahaan Sub Sektor Perkebunan yang terdaftar di Bursa Efek Indonesia periode 2011-2017.

\section{Uji Parsial (Uji t)}

Uji $\mathrm{t}$ digunakan untuk mengetahui apakah variabel-variabel independen secara parsial berpengaruh signifikan atau tidak signifikan terhadap variabel dependen. Hasil uji t dalam penelitian ini dapat dilihat pada tabel 9:

Tabel 9. Hasil Uji t

\begin{tabular}{|c|c|c|}
\hline Model & $\mathrm{t}$ & Sig. \\
\hline (Constant) &, 352 & ,726 \\
\hline 1 TAR & 3,546 & ,001 \\
\hline SIZE &,- 326 & ,746 \\
\hline
\end{tabular}

a. Dependent Variable: LTDER

Sumber: Hasil pengolahan data (2019)

Berdasarkan tabel 9, maka dapat diketahui pengaruh masing-masing variabel independen terhadap variabel dependen sebagai berikut:

1. Tangibility of Asset Ratio memiliki nilai

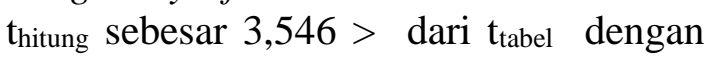
$\mathrm{df}=\mathrm{n}-\mathrm{k}-1$ (49-2-1) sebesar 2,01290. Jadi $t_{\text {hitung }}>\mathrm{t}_{\text {tabel }}(3,546>2,01290)$ atau dengan nilai taraf signifikan $0,001<0,05$ maka $\mathrm{H}_{0}$ ditolak, artinya struktur aset berpengaruh positif dan signifikan terhadap struktur modal pada Perusahaan Sub Sektor Perkebunan yang terdaftar di Bursa Efek Indonesia periode 2011-2017. 
2. Size memiliki nilai thitung sebesar $0,326<$ dari $t_{\text {tabel }}$ dengan $\mathrm{df}=\mathrm{n}-\mathrm{k}-1$ (49-2-1) sebesar 2,01290. Jadi $t_{\text {hitung }}<\mathrm{t}_{\text {tabel }}(0,326$ $<2,01290)$ atau dengan nilai taraf signifikan $0,746>0,05$ maka $\mathrm{H}_{0}$ diterima, artinya ukuran perusahaan berpengaruh negatif dan tidak signifikan terhadap struktur modal pada Perusahaan Sub Sektor Perkebunan yang terdaftar di Bursa Efek Indonesia periode 2011-2017.

\section{Pembahasan}

\section{Pengaruh Struktur Aset Terhadap Struktur Modal}

Struktur aset menggambarkan sebagian jumlah aset yang dapat dijadikan jaminan. Secara umum, perusahaan yang memiliki aset yang dapat digunakan sebagai agunan hutang cenderung menggunakan hutang relatif lebih besar. Berdasarkan uji regresi linear berganda struktur aset berpengaruh positif terhadap struktur modal. Hasil uji t struktur aset berpengaruh positif dan signifikan terhadap struktur modal pada Perusahaan Sub Sektor Perkebunan yang terdaftar di Bursa Efek Indonesia periode 2011-2017. Hal ini sejalan dengan pendapat Brigham dan Joel (2006), "perusahaan yang aktivanya cocok sebagai jaminan atas pinjaman cenderung lebih banyak menggunakan utang. Aktiva untuk tujuan umum yang dapat digunakan oleh banyak bisnis dapat menjadi jaminan yang baik, dan sebaliknya pada aktiva untuk tujuan khusus. Hal tersebut sejalan dengan penelitian yang dilakukan Batubara, Topowijono dan Zahro (2017), Ginting (2017), dan Widyaningrum (2015). Berdasarkan penelitian di atas maka penulis dapat menyimpulkan bahwa struktur aset dapat digunakan untuk menentukan seberapa besar hutang jangka panjang yang dapat diambil dan hal ini akan berpengaruh terhadap penentuan besarnya struktur modal.

\section{Pengaruh Ukuran Perusahaan Terhadap Struktur Modal}

Ukuran perusahaan adalah nilai yang menunjukkan besar kecilnya perusahaan yang ditunjukkan oleh total aset, jumlah penjualan, rata-rata total penjualan dan rata- rata total aset. Berdasarkan uji regresi linear berganda bahwa ukuran perusahaan berpengaruh negatif terhadap struktur modal. Dan hasil uji $t$ bahwa ukuran perusahaan berpengaruh negatif dan tidak signifikan terhadap struktur modal pada Perusahaan Sub Sektor Perkebunan yang terdaftar di Bursa Efek Indonesia periode 2011-2017. Hal tersebut tidak sesuai dengan pendapat Sawir (2004), "ukuran perusahaan menggambarkan ukuran besar kecilnya suatu perusahaan yang ditunjukkan oleh total aset, jumlah penjualan, rata-rata total penjualan dan rata-rata total aset. Semakin besar ukuran perusahaan menunjukkan semakin tinggi kemampuan perusahaan mendapatkan modal di pasar modal dan semakin besar perusahaan, maka akan semakin tinggi pula dana yang dibutuhkan untuk membiayai kebutuhan perusahaan. Serta penelitian yang dilakukan oleh Batubara, Topowijono, dan Zahro (2017), Santoso (2016).

Penelitian ini sejalan dengan penelitian yang dilakukan oleh Lessy (2015), Widyaningrum (2015), dan Hakim (2013). Berdasarkan penelitian di atas maka penulis dapat menyimpulkan ukuran perusahaan yang besar memiliki peluang serta kepercayaan lebih besar dalam mendapatkan sumber dana, sehingga akan memudahkan perusahaan untuk mendapatkan kredit dari pihak luar.

\section{KESIMPULAN DAN SARAN}

\section{Kesimpulan}

Dari hasil pengujian hipotesis dan evaluasi yang telah dijabarkan oleh penulis, maka dapat ditarik kesimpulan struktur aset berpengaruh positif dan ukuran perusahaan berpengaruh negatif terhadap struktur modal pada Perusahaan Sub Sektor Perkebunan yang terdaftar di Bursa Efek Indonesia periode 2013-2017. Hasil koefisien korelasi dan determinasi, diperoleh koefisien korelasi (r) yang menunjukkan bahwa terdapat hubungan yang sedang antara struktur aset dan ukuran perusahaan dengan struktur modal. Sementara koefisien determinasi ( $\mathrm{R}$ square) menunjukkan bahwa 
tinggi rendahnya struktur modal dipengaruhi oleh struktur aset dan ukuran perusahaan. Hasil uji $\mathrm{F}$ diperoleh bahwa struktur aset dan ukuran perusahaan berpengaruh signifikan terhadap struktur modal pada Perusahaan Sub Sektor Perkebunan yang terdaftar di Bursa Efek Indonesia periode 2011-2017. Uji t diperoleh bahwa struktur aset berpengaruh signifikan terhadap struktur modal dan variabel ukuran perusahaan berpengaruh tidak signifikan terhadap struktur modal pada Perusahaan Sub Sektor Perkebunan yang terdaftar di Bursa Efek Indonesia periode 2011-2017.

\section{Saran}

Berdasarkan kesimpulan dan hasil evaluasi penelitian yang telah dijelaskan, maka penulis memberikan beberapa saran, yaitu struktur aset perusahaan sebaiknya dapat meningkatkan struktur aset, perusahaan dapat menambah aset tetap dengan catatan aset tetap perusahaan digunakan dan dikelola untuk mendukung peningkatan penjualan. Aset tetap tersebut juga dapat digunakan sebagai jaminan jangka panjang. Ukuran perusahaan, sebaiknya perusahaan dapat lebih efektif dalam mengelola asetnya untuk mendukung peningkatan penjualan. Total aset yang meningkat jika tidak dibarengi dengan peningkatan penjualan, mengindikasikan bahwa masih terdapat aset-aset yang menganggur yang tidak mampu menghasilkan penjualan. Untuk struktur modal, sebaiknya perusahaan meningkatkan proporsi penggunaan utangnya, sehingga struktur modal tetap optimal dan perusahaan tetap dapat menjamin kelangsungan hidup perusahaan di masa yang akan datang. Dengan catatan utang jangka panjang yang diperoleh perusahaan dari pihak kreditur digunakan perusahaan untuk mendukung penjualan dalam meningkatkan laba.

\section{DAFTAR PUSTAKA}

Batubara, Riski Ayu Pratiwi, Topowijono dan Zahro Z.A. 2017. Pengaruh Struktur aktiva, Ukuran perusahaan dan Profitabilitas Terhadap struktur
Modal (Studi pada Perusahaan Makanan dan Minuman yang Terdaftar di Bursa Efek Indonesia Tahun 2012-2015). Malang: Universitas Brawijaya. Jurnal

Brigham, Eugene F., dan Joel F. Houston. 2011. Dasar-dasar Manajemen Keuangan. Edisi 11. Jilid Satu Jakarta: Salemba Empat.

Ginting, Leni Kezia Sari. 2017. Pengaruh Struktur Aktiva, Profitabilitas, Pertumbuhan Penjualan dan Risiko Bisnis Terhadap Struktur Modal Perusahaan Properti dan Real Estate yang Terdaftar di Bursa Efek Indonesia. Medan: Universitas Sumatera Utara. Skripsi

Hery. 2017. Kajian Riset Akuntansi: Jakarta: Grasindo.

Horne, James C. Van dan John M. Wachowicz. 2012. Prinsip-prinsip Manajamen Keuangan. Buku Satu. Edisi 13. Jakarta: Salemba Empat.

Lessy, Devi Anggriyani. 2016.Pengaruh Ukuran perusahaan, Likuiditas, Profitabilitas dan Struktur Aktiva Terhadap Struktur Modal pada Perusahaan Manufaktur yang Terdaftar di Bursa Efek Indonesia. Yogyakarta: universitas Negeri Yogyakarta. Skripsi

Rudianto. 2012. Pengantar Akuntansi

Konsep dan Teknik Penyusunan

Laporan Keuangan. Jakarta : Erlangga

Santoso, Yuswanandre. 2016.Pengaruh Profitabilitas, Ukuran Perusahaan, Struktur Aktiva, Likuiditas dan Growth Opportunity Terhadap Struktur Modal Perusahaan Manufaktur yang Terdaftar di Bursa Efek Indonesia Tahun 2010-2015. Yogyakarta: Universitas Negeri Yogyakarta. Skripsi.

Sawir, Agnes. 2004. Kebijakan Pendanaan dan Restrukturisasi Perusahaan. Jakarta: PT. Gramedia Pustaka Utama 
Sudana, I Made. 2011. Manajamen Keuangan Perusahaan Teori dan Praktek. Jakarta : Erlangga

Wahome, Michael Njogu, F. Memba and Willy Muturi. 2015. The Effect of Firm Size and Capital Risk On Capital Structure Decisions of Insurance Industry in Kenya. International Journal of Scientific and Research Publications.

\section{PROFIL SINGKAT}

Verda Desi Yolanda Panggabean, lahir pada tanggal 05 Desember 1996 di Kota Pematangsiantar. Meraih Gelar S-1 Akuntansi di Sekolah Tinggi Ilmu Ekonomi Sultan Agung Pada Tahun 2019. Ady Inrawan, lahir pada tanggal 10 Februari 1970 di Kota Tanjung Pinang. Meraih Gelar S-1 Akuntansi di Sekolah Tinggi Ilmu Ekonomi Sultan Agung. Menyelesaikan Program Pascasarjana pada program studi Magister Manajemen di Universitas HKBP Nommensen Medan pada tanggal Tahun 2013, dan Sekarang sedang melanjutkan Program Doktoral di Universitas Pasundan Bandung. Hery Pandapotan Silitonga, lahir pada tanggal 03 Nopember 1987 di Kota Tanjung Pinang. Meraih Gelar S-1 Akuntansi di Sekolah Tinggi Ilmu Ekonomi Sultan Agung Pada tahun 2016. Menyelesaikan Program Pascasarjana pada program studi Magister Akuntansi di Universitas Muhammadiyah Sumatera Utara pada tanggal 12 Oktober 2018. Lenny Dermawan Sembiring, lahir pada tanggal 15 Oktober 1994 di Kota Medan. Meraih Gelar S-1 Akuntansi di Sekolah Tinggi Ilmu Ekonomi Sultan Agung Pada tahun 2016. Menyelesaikan Program Pascasarjana pada program studi Magister Akuntansi di Universitas Muhammadiyah Sumatera Utara pada tanggal 12 Oktober 2018. 